\title{
Kinerja Bidang Izin Mendirikan Bangunan di Kantor Kecamatan Subang Kabupaten Subang
}

\author{
Luki Natika1 \\ Fakultas Ilmu Administrasi Universitas Subang \\ lukinatika85@gmail.com
}

Nuraida ${ }^{2}$

Fakultas Ilmu Administrasi Universitas Subang nuraida_74@yahoo.com

\begin{abstract}
Abstrak
Penelitian ini membahas hal-hal yang berkaitan dengan Kinerja Bidang Ijin Mendirikan Bangunan di Kecamatan Subang Kabupaten Subang dalam hubungannya dengan teori menurut Dwiyato yaitu Produktivitas, Kualitas Layanan, Responsitas, Responbilitas, dan Akuntabilitas. Dalam Penelitian ini menggunakan metode penelitian deskriptif kualitatif, melalui observasi, wawancara dan studi dokumentasi. Sumber data diperoleh dari informan dan melalui wawancara dan dokumen diperoleh dalam bentuk peraturan-peraturan dan pengolahan data. Hasil penelitian menunjukkan Kinerja Bidang Ijin Mendirikan Bangunan di Kecamatan Subang Kabupaten Subang Belum Optimal diantaranya Produktivitas, Kualitas Layanan, Responsitas, dan Responbilitas. Hal tersebut perlu diperhatikan agar Produktivitas, Kualitas Layanan, Responsitas, dan Responbilitas Optimal.
\end{abstract}

Kata Kunci: Kinerja Bidang Ijin Mendirikan Bangunan

\section{Abstract}

This study discusses matters relating to the Performance of Building Permit in Subang Regency in relation to the theory according to Dwiyato namely Productivity, Service Quality, Responsibility, Responsibility, and Accountability.In this study using descriptive qualitative research methods, through observation, interviews and documentation studies. Sources of data obtained from informants and through interviews and documents obtained in the form of regulations and data processing. The results showed that the Performance of Building Permit in Subang Sub-District, Subang District Not Optimal, including Productivity, Service Quality, Responsibility, and Responsibility. This needs to be considered so that Productivity, Service Quality, Responsibility, and Optimal Responsibility.

Keywords: Building Permit Performance 


\section{Pendahuluan}

Kinerja organisasi merupakan sebuah alat ukur untuk menilai dan mengevaluasi berhasil atau tidak tujuan organisasi. Kinerja didefinisikan sebagai suatu gambaran tentang tingkatan maupun hasil pencapaian dari sebuah proses pelaksanaan baik kegiatan, program maupun kebijakan dalam rangka mewujudkan hal-hal yang telah tertuang dalam perumusan skema strategis organisasi yang baik.

Organisasi publik diharapakan dapat memenuhi kebutuhan masayarakat yang semakin tinggi. Organisasi tersebut harus sealalu melakukan perubahan kinerjanya ke arah perbaikan, untuk itu segala hambatan yang ada dan perkembangan teknologi yang semakin maju. Sebagai konsekkuensi logis dari kompleksitas tantangan dinamika lingkungan global dan lokal ( regional ) pada berbagai sektor dewasa ini seluruh organisasi terutama organisasi pemerintah, termasuk pemerintah yang dibawah yaitu kecamatan untuk merubah paradigma kinerjanya. Seluruh sumber daya yang dimiliki oleh organisasi pemerintah dikonsentrasikan kepada kinerja bidang izin mendirikan bangunan.

Sejak diberlakukannya UU. No 34 Tahun 2004 tentang otonomi daerah tentang pertimbangan keuangan antara pusat dan daerah, menyebabkan perubahan pada penyelenggaraan pemerintahan dari sentralis menjadi desentralis, dan perubahan sistem baru bagi pembangunan di daerah membawa implikasi terbukanya peluang pembangunan dengan pendekatan yang lebih sesuai dengan karakteristik wilayah. Pembangunan dengan pendekatan tersebut akan memberi peluang pada percepatan pembanguna daerah termasuk pembangunan daerah yang realtif masih terbengkalai. Dalam menghadapi era globalisasi yang penuh tentangan dan peluang, pemerintah daerah harus mampu untuk melakukan inovasi dalam peningkatan kualitas pelayanan publik sehingga kesan birokrasi pemerintah yang lambat, berbelit-belit, kurang ramah dapat dihapuskan.

IMB sangat erat kaitannya dengan pertanahan dan setiap warga berhak memanfaatkan tanah baik untuk bangunan maupun untuk tempat tinggal sebagaimana tertuang dalam undang-undang pokok agraria Nomor 5 tahun 1960 pasal 6 " semua hak atas tanah mempunyai fungsi sosial " dan dalam undang-undang dasar 1945 pasal 33 ayat (3) " hukum agraria meliputi H.pertanahan (Bumi), H.Perairan (Laut), H.pertambangan (Kekayaan alam)" disamping itu hukum yang berkualitas bumi, air dan ruang angkasa ialah hukum dat sepanjang tidak bertentangan dengan kepentingan nasional dan negara.

Dalam mendirikan bangunan pemerintah daerah mengadakan pembangunan berupa pembangunan fisik maupun non fisik. Pembangunan fisik misalnya pembangunan jalan, jembatan, perumahan, gedung sekolah, dll. Sedangankan pembangunan non fisik berupa peningkatan mutu kesehatan, peningkatan mutu pendidikan, dll. Pembangunan yang dilakuakan tanpa pemikiran yang matang akan berdampak negatif pada bangunan itu sendiri dan juga pada lingkungan, contohnya pengaruhnya terhadap lingkungan adalah terjadinya bencana alam (Banjir), pencemaran, penurunan hasil pertanian, dll. Agar tidak terjadi permasalahanpermasalahan demikan maka diperlakuakan adanya pengaturan. 
Pembangunan yang demikian harus ada izin untuk mendirikan bangunan-bangunan tersebut, untuk bangunan berupa gedung izin dalam mendirikan bangunan tersebut merupakan suatu persyaratan bangunan hal ini diatur dalam perda No.5 Tahun 2011 pasal 7 ayat (1) "setiap bangunan harus memenuhi persyaratan administrastratif dan persyaratan teknis sesuai dengan fungsi bangunan".

Salah satu kebijakan Kecamatan Subang adalah bangunan yang tidak memiliki izin dapat terkena sanski baik sanski administratif maupun sanski pidana karena telah melanggar aturan daerah. Dalam kebijakan prosedur dalam permohonan mendirikan bangunan terdapat banyak hambatan atau permasalahan untuk memperoleh izin mendirikan bangunan tersebut. Bnyak faktor yang menjadi memicu hambatan atau permasalahan tersebut tidak hanya dari kecamatan namun juga warga khususnya dari warga kecamatan subang, selain itu pemeberian IMB selalu membutuhkan prosedur yang panjang dan cenderung berbelit-belit, warga kecamatan subang yang ingin mengurus IMB harus memperoleh keterangan terlebih dahulu.

Dalam pelaksanaan tugasnya untuk pelaksanaan publik di wilayah Kecamatan Subang Kabupaten Subang untuk meningkatkan kinerja dalam perizinan IMB dapat ditempuh dengan pengelolaan kinerja organisasi sesuai dengan peraturan yg ada. Maka Kecamatan Subang memerlukan suatu sistem informasi yang bersifat digital yang berguna untuk membantu aparatur yang terkait dalam menyelenggarakan penerbitan perizinan IMB sesuai dengan tugas pokok dan fungsinya sehari-hari agar semakin baik. Berikut tabel target dan realisasi retribusi IMB :

Tabel 1

Target dan Realisasi Retribusi IMB

Tahun 2018 - 2019

\begin{tabular}{|c|l|c|c|}
\hline Tahun & \multicolumn{1}{|c|}{ Target \& Realisasi } & Jumlah & Persen \% \\
\hline \multirow{2}{*}{2018} & 1. Target & 5.890 & \multirow{2}{*}{59,42} \\
& 2. Realisasi & 3.500 & \\
\hline \multirow{2}{*}{2019} & 1. Target & 8.770 & 63,51 \\
& 2. Realisasi & 5.570 & \multirow{2}{*}{} \\
\hline
\end{tabular}

Di sisi lain, untuk Kecamatan Subang tetap banyak ditemui bangunan atau usaha perdagangan yang belum mengantongi IMB. Padahal IMB ini menjadi bukti penting dalam status legal sebuah bangunan yang direncanakan sesuai yang ditentukan oleh pemohon. Perizinan IMB ini sangat penting bagi masyarakat Kecamatan Subang karena untuk menunjukan kepemilikan suatu bangunan, masyarakat harus dapat menunjukan IMB nya. Berikut merupakan tabel perkembangan bangunan ber-IMB di Kecamatan Subang.

Tabel 2

Perkembangan Bangunan Ber-IMB Kecamatan Subang

\begin{tabular}{|c|c|c|c|c|}
\hline Tahun & Jumlah Bangunan & $\begin{array}{c}\text { Jumlah Bangunan } \\
\text { Ber-IMB }\end{array}$ & Target & Realisasi \\
\hline 2018 & 6,157 & 2,633 & $34 \%$ & $25 \%$ \\
\hline
\end{tabular}


Volume 2 Issue 2, Desember 2020

http://ejournal.unsub.ac.id/index.php/publik

\begin{tabular}{|l|l|l|l|l|}
\hline 2019 & 6,353 & 4,172 & $42 \%$ & $38 \%$ \\
\hline
\end{tabular}

Meskipun data yang ada masih terbatas sampai pada tahun 2019, namun bila dilihat secara seksama diketahui bahwa target-target yang telah ditentukan tidak pernah tercapai. Adapun permasalahan tersebut yaitu belum sesuai antara kebijakan pemerintah dengan masyarakat yang menginginkan penerbitan surat IMB yang murah, cepat. Kecamatan Subang untuk menggabungkan prosedur dan tahap pengurusan IMB sehingga mempermudah proses perizinan, mengurangi penumpukan berkas, memangkas waktu pengurusan agar lebih singkat, serta tidak adanya lagi praktik curang antara pemohon dan pihak aparatur sehingga tercipta peningkataan kinerja dan percepatan penerbitan surat perizinan kepada masyarakat. Berdasarkan fenomena di atas peneliti berambisi bahwa Kinerja bidang izin mendirikan bangunan belum optimal dengan indikator sebagai berikut :

1. Efektivitas dalam Kinerja Bidang IMB belum optimal, dilihat dari masih banyak bangunan di Kecamatan Subang yang belum memiliki IMB

2. Efesiensi dalam Kinerja Bidang IMB belum optimal, karena dilihat dari pembuatan IMB yang belum sesuai dengan harapan masyarakat yaitu murah dan cepat

\section{Kerangka Teori}

\section{Konsep Kinerja}

Kinerja adalah sebuah kata dalam bahasa Indonesia dari kata dasar kerja yang meterjemahankan kata dari bahasa asing prestasi bisa pula berarti hasil kerja. Suatu organisasi jika ingin maju atau berkembang maka dituntut untuk memiliki pegawai yang berkualitas. Pegawai yang berkualitas adalah pegawai yang kinerjanya dapat memenuhi target atau sasaran yang ditetapkan oleh perusahaan. Untuk memperoleh pegawai yang memiliki kinerja baik maka diperlukan penerapan kinerja. Kinerja dapat dilihat dari sisi jumlah dan mutu tertentu sesuai dengan standart yang telah ditetapkan oleh organisasi atau perusahaan bentuknya dapat bersifat tangible (dapat ditetapkan alat ukurnya atau standarnya) atau intangible (tak dapat ditetapkan alat ukurnya atau standarnya), tergantung pada bentuk dan proses pelaksanaan pekerjaan itu.

Kinerja atau yang sering disebut performance adalah hasil kerja atau tingkat pencapaian dari aktivitas kerja untuk meraih tujuan organisasi. Secara umum kinerja diartikan sebagai pencapaian hasil atau tingkat pencapaian tujuan organisasi (Rue dan Byars dalam Yudoyono, 2011). Dengan demikain, yang dimaksud dengan hasil adalah hasil kerja yang dilakukan oleh individu atau sekelompok orang ataupun institusi dalam mencapai tujuan organisasi. Kinerja menurut mangkunegara $(2000 ; 67)$ Kinerja (prestasi kerja) adalah hasil kerja secara kualitas dan kuantitas yang dicapai oleh seseorang pegawai dalam melakasanakan tugasnya sesuai dengan tanggung jawabnya yang diberikan kepadanya. Menurut sulistiyani (2003:223) mengemukakan Kinerja seseorang merupakan kombinasi dari kemampuan usaha dan kesempatan yang dapat dinilai dari hasil kerja. Hasibuan (2001:34) mengemukakan Kinerja adalah suatu hasil kerja yang dicapai seorang dalam melaksanakan tugas yang dibebankan kepadanya yang didasarkan atas kecakapan, pengalaman, dan kesungguhan serta 
waktu. Pernyataan Indra Bastian dalam Fahmi (2015:2) menyatakan bahwa kinerja adalah gambaran mengenai tingkat pencapaian pelaksanaan suatu kegiatan/program/kebijaksanaan dalam mewujudkan sasaran, tujuan, misi dan visi organisasi yang tertuang dalam perumusan skema strategis (strategic planning) suatu organisasi. Sedangkan Menurut Otley (1999) dalam Mahmudi (2005 : 6) kinerja mengacu pada suatu yang terkait dengan kegiatan melakukan pekerjaan, dalam hal ini meliputi hasil yang dicapai kerja tersebut. Kinerja merupakan suatu konstruk yang bersifat multidimensi pengukurannya juga bervariasi tergantung pada kompleksitas faktor-faktor membentuk kinerja. Dengan demikian Kinerja adalah suatu organisasi yang tertuang dalam perumusan skema strategis untuk mencapai hasil pencapaian yang dikerjakan.

\section{Konsep Organisasi}

Pengertian organisasi berbeda-beda satu sama lainnya, walaupun demikian penegrtian tersebut mempunyai elemen-elemen dasar yang sama. Dalam pengertian yang sederhana organisasi sering diartikan sebagai kelompok orang yang bekerjasama dan ingin mencapai tujuan bersama. Oraganisasi didirikan karena beberapa tujuan tertentu hanya dapat dicapai melaui tindakan yang harus dilakukan secara bersama-sama, apakah tujuan itu berupa laba, pemberian pendidikan, sosial dan lain-lain. Adapun pengertian oraganisasi menurut para ahli, antara lain Atmosudirjo dalam buku khaerul umam (2012:19) mendefinisikan Organisasi adalah struktur tata pembagian kerja dan struktur tata hubungan kerja antar sekelompok orang-orang pemegang posisi yang bekerjasama secara teretentu untuk bersamasama mencapai suatu tujuan tertentu. Menurut Luther Gulick dalam buku inu kencana syfiie (2006:52) mendefinisikan : Organisasi adalah sebagai suatu alat saling berhubungan satuan-satuan kerja yang memberikan mereka kepada orang-orang yang ditempatkan dalam stuktur kewenangan. Jadi dengan demikian pekerjaan dapat dikoordinasikan oleh perintah para atasan kepada para bawahan yang menjangkau dari puncak sampai ke dasar dari seluruh badan usaha".

\section{Kinerja Organisasi}

Kinerja organisasi merupakan indikator tingkat prestasi yang dapat dicapai dan mencerminkan keberhasilan suatu organisasi, serta merupakn hasil yang dicapai dari perilaku oraganisasi. Menurut Atmosuddirjo dalam Pasolong (2010:176) mengatakan bahwa : Kinerja organisasi adalah sebagai evektivitas organisasi secara menyeluruh untuk kebutuhan yang ditetapkan dari setiap kelompok yang berkenaan melalui usaha-usaha yang sistematik dan mengikat kemapuan organisasi secara terus menerus untuk mencapai kebutuhannya secara efektif". Berdasarkan pendapat tersebut, diketahui bahwa kinerja organisasi merupakan organisasi yang efektif disertai kebutuhan-kebutuhan yang telah ditetapkan dari hasil kerjasama kelompok yang terjalin secara rapi untuk meningkatkan kemampuan organisasi itu sendiri. Menurut Street (2003:67) pengertian kinerja organisasi adalah : “Tingkat yang menunjukan seberapa jauh pelaksanaan tugas dapat dijalankan secara aktual dan misi organisasi tercapai. Dari definisi tersebut dapat dipahami bahwa kinerja organisasi adalah seberapa jauh tingkat kemampuan pelaksanaan tugas-tugas organisasi dalam rangka pencapaian tujuan sesuai dengan kemampuan yang dimiliki dan 
program/kebijakan/visi dan misi yang telah ditetapkan sebelumnya. Pengertian kinerja dalam organisasi merupakan jawaban dari berhasil atau tidak nya tujuan organisasi yang telah ditetapkan. Para intansi sering tidak memperhatikan kinerja instansi atau organisasi". Dari definisi diatas dapat dipahami bahwa kinerja organisasi adalah seberapa jauh tingkat kemampuan pelaksanaan tugas-tugas organisasi dalam rangka pencapaian tujuan sesuai dengan kemampuan yang dimiliki dan program kebijakan visi dan misi yang telah ditetapkan sebelumnya. Pengertian kinerja dalam organisasi merupakan jawaban dari berhasil atau tidaknya tujuan oraganisasi yang telah ditetapkan. Para intansi sering tidak memperhatikan kinerja instansi atau organisaisi kecuali kinerja sudah amat buruk.

Kinerja suatu organisasi dapat dilihat dari tingkat sejauh mana organisasi dapat mencapai tuuan yang didasarkan pada visi dan misi yang sudah ditetapkan sebelumnya. Untuk itu, diperlukan beberapa informasi tentang kinerja organisasi. Informasi tersebut dapat digunakan untuk melakuakan evaluasi terhadap proses kinerja yang dilakukan organisiasi selama in, sudah sejalan dengan tujuan yang diharapakan atau belum. Faktanya, banyak organisasi tidak mempunyai informasi tentang kinerja dalam organisasi.

\section{Faktor-Faktor Yang Mempengaruhi Kinerja}

Menurut Soesilo (2000) dalam Tangkilisan (2005:180-181) bahwa faktor yang mempengaruhi kinerja organisasi yaitu :

1) Struktur organisasi sebagai bangunan internal yang berkaitan dengan fungsi yang menjalankan aktivitas organisasi.

2) Kebijakan pengelolaan; berupa visi dan misi organisasi

3) Sumber daya manusia, yang berkaitan dengan kualitas karyawan untuk bekerja dan berkarya secara optimal

4) Sistem informasi manajemen, yang berhubungan dengan pengelolaan data base untuk digunakan dalam mempertinggi kinerja organisasi.

5) Sarana dan prasarana yang di miliki, yang berhubungan dengan penggunaan teknologi bagi penyelenggaraan organisasi pada setiap aktivitas organisasi.

Berdasarkan uraian diatas maka dapat disimpulkan bahwa faktor-faktor yang mempengaruhi dalam kinerja yaitu Struktur organisasi, Kebijakan pengelolaan, sistem informasi manajemen, sarana dan prasarana, dan sumber daya manusia. Dengan adanya faktor tersebut, maka di suatu intansi pemerintah daerah harus melakukan penilaian kinerja di organisasi publik tersebut.

\section{Indikator Kinerja}

Indikator kinerja adalah ukuran kuantitatif dan kualitatif yang menggambarkan tingkat pencapaian suatu sasaran atau tujuan yang telah ditetapkan (Mahsun, 2006:71). Sementara menurut Lohman dalam Mahsun, (2006:71) indikator kinerja adalah suatu variabel yang digunakan untuk mengekspresikan secara kuantitatif efektifitas dan efisiensi proses dengan pedoman pada target-target dan tujan organisasi. Berdasarkan beberapa definisi diatas, indikator kinerja adalah kriteria yang digunakan untuk menilai keberhasilan pencapaian tujuan organisasi yang diwujudkan dalam ukuran-ukuran tertentu. Untuk menilai kinerja organisasi ini tentu saja diperlukan indikator-indikator atau kriteria-kriteria untuk mengukurnya 
secara jelas, tanpa indikator yang jelas tidak akan dapat digunakan untuk menentukan mana yang relative lebih efektif diantara alternative alokasi sumber daya yang berbeda, alternative desain-desain organisasi yang berbeda, diantara pilihanpilihan pendistribusian tugas dan wewenang yang berbeda. Indikator kinerja atau performance indicators kadang-kadang dipergunakan secara bergantian dengan ukuran kinerja (performance measures). Pengukuran kinerja berkaitan dengan hasil yang dapat dikuantitatifkan dan mengusahakan data setelah kejadian. Sementara itu. Indikator kinerja dapat dipakai untuk aktivitas yang hanya dapat diterapkan secara lebih kualitatif atas dasar prilaku yang dapat diamati, Wibowo (2016:86). Kinerja memerlukan adanya dukungan sarana, kompetensi, peluang, standar, dan umpan balik. Kaitan diantara ketujuh indikator tersebut digambarkan oleh Hersey, Blanchard, dan Johnson dalam Wibowo (2016 : 86) dengan penjelasan seperti berikut :

1. Tujuan, merupakan keadaan yang berbeda yang secara aktif dicari oleh seorang individu atau organisasi untuk dicapai. Pengertian tersebut mengandung makna bahwa tujuan bukanlah merupakan persyaratan, juga bukan merupakan sebuah keinginan.

2. Standar, mempunyai arti penting karena memberitahukan kapan suatu tujuan dapat diselesaikan. Standar merupakan suatu ukuran apakah tujuan yang diinginkan dapat dicapai. Tanpa standar, tidak dapat diketahui kapan suatu tujuan tercapai.

3. Umpan balik, melaporkan kemajuan, baik kualitas maupun kuantitas, dalam mencapai tujuan yang didefinisikan oleh standar. Umpan balik terutama penting ketika kita mempertimbangkan real goals atau tujuan sebenarnya.

4. Atat atau sarana, merupakan sumber daya yang dapat dipergunakan untuk membantu menyelesaikan tujuan dengan sukses. Alat atau sarana merupakan faktor penunjung untuk pencapaian tujuan.

5. Kompetensi merupakan persyaatan utama dalam kinerja. Kompetensi merupakan kemampuan yang dimiliki oleh seseorang untuk menjalankan pekerjaan yang diberikan kepadanya dengan baik.

6. Motif merupakan alasan atau pendorong bagi seseorang untuk melakukan sesuatu. Manajer memfasilitasi motivasi kepada karyawan dengan insentif berupa uang, memberikan pengakuan, menetapkan tujuan, menentang, menetapkan standar terjangkau, meminta umpan balik, memberikan kebebasan melakukan pekerjaan termasuk waktu melakukan pekerjaan, menyediakan sumber daya yang diperlukan dan menghapus tindakan yang mengakibtakan disintensif.

7. Peluang pekerja perlu mendapatkan kesempatan untuk menunjukan prestasi kerjanya. Terdapat dua faktor yang menyumbangkan pada adanya kekurangan kesempatan untuk berprestasi, yaitu ketersediaan waktu dan kemampuan untuk memenuhi syarat.

Menurut Kumorotomo (1996) dalam Sudarmanto (2015:16-17) merumuskan 4 indikator penilaian terhadap kinerja organisasi, yaitu:

a. Efesiensi: menyangkut pertimbangan tentang keberhasilan organisai pelayanan publik mendapatkan laba,memanfaatkan faktor-faktor produksi serta pertimbangan yang berasal dari rasionalitas ekonomi

b. Efektivitas: menyangkut rasionalitas teknis, nilai, misi, tujuan organisasi serta fungsi agen pembangunan. 
c. Keadilan: menyangkut distribusi dan alokasi layanan yang diselenggarakan organisasi pelayanan publik.

d. Daya tanggap: daya tanggap terhadap kebutuhan vital masyarakat, dan dapat dipertanggungjawabkan secara transparan.

Selanjutnya, Dwiyanto (2002) dalam Sudarmanto (2015:16) mengemukakan terdapat 5 indikator untuk mengukur kinerja organisasi, yaitu:

a. Produktivitas: dengan mengukur tingkat efesiensi,efektivitas pelayanan,dan tingkat pelayanan publik dalam rangka mencapai hasil yang di harapkan.

b. Kualitas layanan: dengan mengukur kepuasan masyarakat terhadap layanan yang di berikan.

c. Responsitas: dengan mengukur kemampuan organisasi untuk mengenali kebutuhan masyarakat,menyusun agenda dan prioritas pelayanan,dan mengembangkan program-program pelayanan publik sesuai dengan kebutuhan dan aspirasi masyarakat.

d. Responsibilitas: menjelaskan \mengukur kesesuaian pelaksanaan kegiatan organisasi publik yang di lakukan dengan prinsip-prinsip administrasi yang benar atau sesuai dengan kebijakan organisasi

e. Akuntabilitas: seberapa besar kebijakan dan kegiatan organisasi publik tunduk pada para pejabat politik yang dipilih oleh rakyat atau ukuran yang yang menunjukan tingkat kesesuaian penyelenggaraan pelayanan dengan ukuran nilainilai atau norma eksternal yang ada di masyarakat atau yang di miliki para stakeholders.

Pengukuran kinerja organisasi publik tidak cukup hanya dilakukan dengan mengunakan indikator-indikator yang melekat pada organisasi publik tersebut, penilaian kinerja dari sisi pengguna jasa ini menjadi sangat penting karena organisasi publik sering kali kewenangan monopolis sehingga para pengguna jasa tidak memiliki alternatif sumber pelayanan. Berbeda dengan organisasi pelayanan yang diselenggarakan pasar, yang pengguna jasa memiliki pilihan sumber pelayanan, dalam pelayanan oleh birokrasi publik penggunaan pelayanan oleh publik sering tidak ada hubungannya sama sekali dengan kepuasannya terhadap pelayanan. Unsur-unsur penilaian kinerja adalah jelas merupakan dasar fundamental dalam kegiatan organisasi yang harus diperhatikan untuk tercapainya suatu rencana yang dapat dipedomani tujuan organisasi. Untuk mencapai tujuan organisasi tersebut perlu adanya kinerjayang tinggi dari oragnisasi itu sendiri.

\section{Tinjauan Umum Tentang Ijin Mendirikan Bangunan}

Secara teoritis verguning/ijin didefinisikan sebagai suatu perbuatan administrative negara yang memperkenakan perbuatan yang secara umum tidak dilarang dalam peraturan perundang-undangan asalkan dilakukan sesuai dengan syarat-syarat teretntu yang ditentukan dalam peraturan hukum yang berlaku (SF Marbun dan Mahfud MD, 2006:95) sedangkan perbuatan hukum publik itu sendiri memiliki penegrtian suatu perbuatan yang dilakukan oleh pejabat administrasi negara yang tindakanya tersebut didasarkan pada peraturan perundang-undangan dan hukum publik.

Pada dasarnya mendirikan bangunan adalah sebuah perbuatan yang berbahaya, hal ini karena bangunan merupakan tempat sentral bagi manusia beraktivitas sehari-hari 


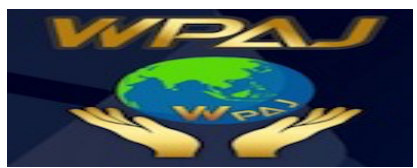

baik ketika dirumah maupun dikantor. Criteria bahaya tersebut muncul ketika bangunan tersebut memiliki syarat tertentu agar tidak rubuh dan mencelakai orang didalam atau sekitarnya. Bangunan didirikan dengan syarat pertimbangan dan perhitungan yang matang mengenai bentuk stuktur dan kekuatan struktur kekuatan baha yang digunakan. Dengan demikian bangunan tersebut akan kuat dan tidak rusak/roboh mencelakai orang didalamnya.

Bangunan yang didirikan tanpa adanya perhitungan mengenai kekuatan stuktur dan bahan maka akan mudah roboh dan menimbulkan bahaya bagi orang banyak. Dalam rangka melindungi keselamatan masyarakat banyak dari bahaya roboh/rusaknya bangunan maka kegiatan pembangunan harus diawasi, boleh dibangun tetapi dengan syarat tertentu. Diantaranya syarat itu salah satunya adalah harus kuat dari segi struktur konstruksi dan bahan yang digunakan, apabila tidak dipenuhi maka kegiatan mendirikan bangunan itu termasuk katagori membahayakan keselamatan masyarakat sehingga ijin mendirikan bangunan tidak diberikan.

Pengawasan pemerintah daerah terhadap kegiatan membangun bangunan dilaksanakan melalui pemberian ijin mendirikan bangunan yang dimohonkan oleh anggota masyarakat yang memberikan gambaran bangunan yang akan didirikan lengkap dengan gambar dan perhitungan struktur konstruksi. Kemudian setelah diteliti dan dipertimbangkan dengan cermat, apabila memenuhi syarat maka ijin tersebut dikeluarkan dan pemohon diwajibkan membayar retribusi guna pemasukan keuangan daerah.

\section{Retribusi Perizinan}

Perizinan pada dasarnya merupakan suatu instrumen kebijakan yang dilakuakan oleh pemerintah dalam upaya mengantur kegiatan-kegiatan yang memiliki peluang timbulnya gangguan bagi kepentingan umum. Melalui mekanisme perizinan ini, pemerintah daerah dapat melakukan pengendalian atas akstemalitasi negative yang mungkin akan timbul atas aktivitas sosial maupun ekonomi, mengalokasikan barang publik secara lebih efisien dan adil, mencegah asimetri informasi, dan perlindungan hukum atas kepentingan atau penyelenggaran kegiatan. Oleh karena itu, pertimbangan yang harus dipikirkan dalam penetapan suatu perizinan adalah :

1) Melindungi kepentingan umum (publik interest)

2) Menghindari ekstemalitas negatif

3) Menjamin pembangunan sesuai dengan rencana, serta standar kualitas minimum yang dibutuhkan.

Retribusi perizinan sendiri termasuk kedalam lincense and permit fees, yaitu retribusi yang dibayarkan yang berhubungan dengan pemberian suatu hak atau izin dari pemerintahan disamping pemberian penjualan langsung barang dan jasa. Pengenaan retribusi juga dimaksudkan untuk mengurangi beban pembayanan pajak dengan cara mengambil kontribusi yang lebih besar dari penerimaan layanan, sehingga pengenaan pungutan atas izin dan keistimewaan lainya lebih menyerupai pajak atas perusahan swasta tersebut. Pungutan tersebut dapat mengkonpensasi tambahan pengeluran pemerintah untuk penyediaan layanan tertentu kepada masyakat yang mengkonsumsinya atau untuk mengganti biaya administrasi.

\section{Metode Penelitian}


Jenis penelitian yang digunakan dalam penelitian ini adalah deskriftif kualitatif, karena penelitian ini bertujuan untuk memperoleh gambaran variabel yang di teliti. Dalam hal penelitian ini penulis mengungkapkan penelitian kualitatif dengan penelitian yang dilakukan dalam setting tertentu yang ada dalam kehidupan sebenarnya dengan maksud memahami fenomena apa yang sedang terjadi yaitu kinerja pembuatan izin mendirikan bangunan di Kantor Kecamatan Subang Kabupaten Subang Dan penelitian kualitatif ini merupakan metode-metode untuk mengeksplorasi dan memahami makna yang oleh sejumlah individu atau sekelompok orang dianggap berasal dari masalah sosial atau kemanusiaan Creswell (2010:4).

Penelitian kualitatif ini menghasilkan atau mengolah data yang sifatnya deskriftif, seperti transkripsi wawancara, catatan lapangan, gambar, photo dan lain-lain. Dalam penelitian kualitatif perlu menekankan pada pentingnya kedekatan dengan orangorang dan situasi penelitian, agar pemeliti memperoleh pemahaman jelas tentang realitas dan kondisi kehidupan nyata. Penulis lebih menekankan pada obyektifitas dan kejujuran yang diwujudkan dengan menjelaskan tujuan kepada informen, sehingga konsekuensi dari hasil penelitian ini tidak berdampak kepada informen yang memberikan informasi.

\section{Hasil dan Pembahasan}

Gambaran Singkat Kecamatan Subang

Visi SKPD Kecamatan Subang adalah “ Terwujudnya Kecamatan Subang HUDANG (Harmoni, Unggul, Dinamis, Aman, Normatif, dan Guyub) Tahun 2018. Sebagai penjabaran atas visi tersebut di atas, ditetapkan Misi Kantor Kecamatan Subang yaitu sebagai berikut :

1) Menciptakan aparatur pemerintah yang unggul dalam memberikan pelayanan publik yang profesional adalah meningkatkan Sumber Daya Manusia (SDM) yang unggul demi memberikan pelayanan yang profesional dan prima kepada masyarakat.

2) Menciptakan Masyarakat yang religius, taat hukum, dan berbudaya adalah upaya meningkatkan aktualisasi norma dan syariat agama yang dianutnya kedalam aktifitas kehidupan baik dalam kehidupan keluarga maupun kehidupan bermasyarakat, meningkatkan rasa memiliki (sense of belonging) dan menjunjung tinggi nilai-nilai luhur budaya bangsa terutama budaya daerah (sunda).

3) Meningkatkan Sinergitas Program Pembangunan dan Pemberdayaan Masyarakat adalah upaya memotivasi dan mendorong masyarakat untuk berperan aktif/guyub terhadap perencanaan program pembangunan, memelihara hasil-hasil pembangunan, serta peningkatan sistem swadaya dan pemberdayaan dalam proses pembangunan.

4) Menciptakan masyarakat yang serasi (Sehat, Rapih, Indah), harmoni dan dinamis berbasis gotong royong, adanya upaya untuk meningkatkan kesadaran masyarakat dalam menjaga kualitas lingkungan hidup yang bersih dan sehat jasmani maupun rohani sehingga mampu menyesuaikan diri dengan perkembangan jaman. 


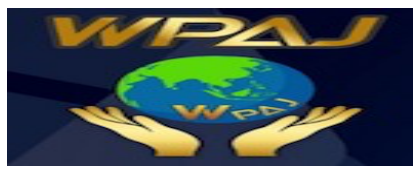

Volume 2 Issue 2, Desember 2020

http://ejournal.unsub.ac.id/index.php/publik

Secara geografis Kecamatan Subang terletak tepat di tengah-tengah pusat pemerintahan Kabupaten Subang, dan merupakan zona pedataran dengan ketinggian $\pm 114 \mathrm{~m}$ diatas permukaan laut, dengan memiliki luas wilayah 5.896,946 Ha yang terdiri dari :

a. Pesawahan : 2.922 .90 ha

b. Darat : $2.974,046$ ha

Serta memiliki batas-batas wilayah administratif sebagai berikut :

- Sebelah Barat berbatasan dengan Kecamatan Dawuan;

- Sebelah Timur berbatasan dengan Kecamatan Cibogo;

- Sebelah Selatan berbatasan dengan Kecamatan Cijambe

- Sebelah Utara berbatasan dengan Kecamatan Pagaden Barat;

Jumlah penduduk Kecamatan Subang berdasarkan data terakhir tahun 2015 sebanyak 124.376 jiwa yang terdiri dari :

a. Laki-laki : 63.162 jiwa

b. Perempuan : 61.205 jiwa

Dengan kepadatan penduduk 2.303 jiwa per $\mathrm{Km} 2$ yang tersebar dengan mata pencaharian heterogen yakni pegawai, perdagangan dan jasa, buruh dan pertanian. Penyelenggaraan pemerintahan di Kecamatan Subang secara administratif terbagi menjadi 8 (delapan) wilayah kelurahan yang meliputi Kelurahan Karanganyar, Sukamelang

\section{Kinerja Bidang Izin Mendirikan Bangunan di Kantor Kecamatan Subang Kabupaten Subang.}

Merujuk salah satu fungsi pemerintahan sekarang adalah sebagai pelayan masyarakat, tentunya seksi pelayanan umum pada SKPD kecamatan Subang haruslah dapat memberikan pelayanan yang baik kepada masyarakat. Hal tersebut juga sesuai dengan Peraturan Bupati Subang Nomor 14 E tahun 2008 tentang Tugas Pokok dan fungsi organisasi kecamatan pada paragraf 7 pasal 16 tentang Seksi pelayanan umum, disitu disebutkan "Seksi pelayanan umum mempunyai tugas pokok pelayanan kepada masyarakat serta menyiapkan dan menyusun petunjuk teknis pemberian pelayanan kepada masyarakat".

Untuk mengetahui kinerja bidang izin mendirikan bangunan di kantor Kecamatan Subang Kabupaten Subang maka sesuai teori Dwiyanto (2002) dalam Sudarmanto (2015:16) ada lima dimensi untuk mengukur kinerja organisasi tersebut yaitu sebagai berikut : 1) Produktivitas, 2) Kualitas Layanan, 3) Responsitas 4) Responsibilitas 5) Akuntabilitas.

Langkah pertama kita akan melihat analisis dari sejauh mana aspek Produktivitas dalam izin mendirikan bangunan di kecamatan subang.

1. Produktivitas

Ketersediaan sarana kelengkapan peralatan pendukung dalam pelayanan tentu sangat diharapkan dalam hal pemberian pelayanan kepada masyarakat. Semakin lengkap dan nyaman sarana pelayanan maka kualitas pelayanan akan semakin baik dan memuaskan masyarakat pengguna layanan. Dimensi Produktivitas berfokus pada dengan mengukur tingkat efesiensi,efektivitas pelayanan,dan tingkat pelayanan publik dalam rangka mencapai hasil yang di harapkan. 
Berikut ini adalah hasil wawancara penulis dengan Kepala Seksi Pelayanan Umum SKPD Kecamatan Subang mengenai bagaimana Seksi Pelayanan umum memberikan kelengkapan dan kenyamanan sarana untuk menunjang aktifitas pelayanan adalah sebagai berikut : " Kita sudah berusaha memberikan kenyamanan dan kelengkapan sarana penunjang pelayanan seperti pemasangan AC, Televisi, mesin antrian, bahan bacaan/koran agar masyarakat merasa nyaman ketika menunggu di ruang pelayanan ini. Namun memang kami akui bahwa ada beberapa bagian yang masih kurang maksimal untuk menunjang kenyamanan pelayanan seperti mesin antrian yang tidak berfungsi, Kursi tunggu yang masih kurang banyak sehingga saat hari tertentu ketika yang mengakses pelayanan datang membludak beberapa orang berdiri karena tidak kebagian kursi.Tapi sejauh ini kami akan terus berupaya memaksimalkan pelayanan kepada masyarakat" (Wawancara tanggal 16 Nopember 2019). Dari pernyataan Informan tersebut di atas dapat disimpulkan bahwa sebagai salah satu penunjang kualitas pelayanan, kelengkapan sarana hendaklah diperhatikan jumlah dan kualitasnya. Sarana penunjang pelayanan hendaklah berfungsi secara optimal. Apabila sarana tersebut tidak ada atau kurang maksimal maka akan berpengaruh pada kepuasan masyarakat pengguna layanan.

Kurangnya ketersediaan fasilitas tersebut diungkapkan oleh warga seperti yang dikatakannya dalam wawancara yang dilakukan oleh peneliti : " Iya nih, AC terasa kurang sejuk jadi masih gerah..kursi di ruang tunggu juga kurang banyak. " (Wawancara tanggal 15 Nopember 2019). Pendapat lain FD (Pria,28 Tahun) menyatakan "Ruangan pelayanan masih terasa sempit menurut saya, kalau bisa ditambah luasnya..". Pendapat lain dari WA (Wanita,31 Tahun) "Mesin antriannya koq ga berfungsi ya, cuma pajangan aja kayanya.."(Wawancara tanggal 15 Nopember 2019). Pendapat lain berbeda seperti pernyataan dari AT (34 Tahun) "Ruangan pelayanan sudah cukup nyaman koq,ada TV dan koran jadi kita ga jenuh saat nunggu pelayanan..Cuma mesin antriannya koq mati ya."

Sesuai dengan Kinerja Organisai menurut Dwiyanto untuk indikator Produktivitas belum memuaskan masyarakat pengguna pelayanan. Evaluasi berkala dan penambahan sarana perlu diupayakan guna mencapai kualitas pelayanan yang optimal. Padahal menurut Dwiyanto Produktivitas merupakan dengan mengukur tingkat efesiensi,efektivitas pelayanan,dan tingkat pelayanan publik dalam rangka mencapai hasil yang di harapkan.(Dwiyanto (2002) dalam Sudarmanto (2015:16))

2. Kulitas Layanan

Kemampuan petugas pelayanan pada Seksi Pelayanan umum dalam hal kesiapan melayani sesuai prosedur dan harus dapat memenuhi harapan pelanggan. Dimensi ini merupakan penilaian kualitas pelayanan yang paling dinamis. Harapan masyarakat terhadap kecepatan dan keterbukaan pelayanan cenderung meningkat dari waktu ke waktu sejalan dengan kemajuan teknologi dan informasi. Berkaitan dengan dimensi ini, sangat dipengaruhi oleh kesiapan pemahaman petugas akan tupoksi nya dan kesiapan mental untuk tidak tergoda oleh sesuatu yang menyalahi aturan. Tingkat kunjungan yang tinggi untuk pelayanan bidang perijinan (IMB dan $\mathrm{HO}$ ) dan non perijinan (paling sering pelayanan pengantar pencetakan KTP dan KK) mempengaruhi petugas untuk berbuat tidak sesuai prosedur dalam hal pengenaan tarif pelayanan. Pada pelayanan perijinan, pengenaan tarif sebenarnya telah diatur dalam perda tentang Retribusi Perijinan Tertentu yaitu nomor 7 tahun 2012 dan untuk 
pelayanan non perijinan baik untuk pengantar pencetakan KTP dan KK, pengantar surat pindah, Surat susunan daftar keluarga, pengantar pinjam ke bank dan lainnya aturan mengenai pengenaan tarif tersebut tidak ada. Beberapa narasumber berpendapat seperti berikut, NG (Wanita,41 tahun,17 Nopember 2019) tentang bagaimana pelayanan di bidang perijinan : "Petugas disini tidak jelas memberikan perincian tarif pembuatan ijin nya a, jadi setelah persyaratannya komplit langsung aja ditebak biaya nya segitu..jadi ke kita nya tidak tau biaya segitu teh perinciannya buat apa aja..." lebih lanjut narasumber mengatakan " sebelumnya saya tau bahwa bikin ijin itu ada biaya nya,tapi perinciannya tidak tau untuk biaya apa aja.." Hal senada juga diungkapkan oleh DW (Pria,37 tahun,17 Nopember 2019) : "Saya juga pernah nganter sodara bikin IMB dan $\mathrm{HO}$ dan tau ada perda nya, cuma tidak tau perhitungan untuk biaya nya,suka langsung ditarif aja ga pernah dikasih tau rinciannya..". Hal lain dituturkan oleh WA (Pria,49 tahun,18 Nopember 2019) tentang bagaimana pelayanan di bidang non perijinan : "pegawai yang di pelayanan pas saya bikin kk dan ktp saya diminta 20 ribu...katanya untuk biaya administrasi..sebenarnya sih a tidak setuju kaya gitu tapi mau gimana lagi ya terpaksa saya ngasih da butuh..tidak setuju sih kalo emang ga ada aturannya tapi tetep dijalankan,itu kan ga bener ya..". SN (Pria,39 tahun, 18 Npember 2019) :" Kalo emang ada aturan nya mah untuk biaya pelayanan bikin kk,ktp atau lainnya ga apa-apa sih,tapi kalo emang ga ada aturannya saya rasa sebaiknya jangan mungut..gitu a"..Hal lain diungkapkan UT (Pria,42 tahun):"..Saya pas waktu bikin pengantar pinjam ke bank diminta biaya administrasi nya..dua puluh ribu". Berikut kutipan wawancara dengan Kepala Seksi Pelayanan Umum : "Memang untuk pelayanan perijinan seperti IMB dan $\mathrm{HO}$ ada perda nya untuk tarif retribusi nya,mungkin pada saat menjelaskan petugas ada yang lupa jadi tidak menjelaskan secara rinci pada warga,ya kami mohon maaf..Untuk pelayanan non perijinan seperti pengantar KK,KTP, surat pindah,SKTM,dll.memang tidak ada dasar nya..karena beberapa petugas kami di pelayanan adalah tenaga sukarela dan honor yang tidak ada gaji nya jadi mungkin itu untuk uang kas..jadi itu buat kebijaksanaan saja.. "

Berdasarkan hasil wawancara tersebut di atas, adanya pengenaan tarif pada pelayanan Non perijinan dan tidak adanya transparansi dalam hal tarif pelayanan perijinan, hal itu merupakan penyimpangan dari bagaimana seharusnya pelayanan yang baik dijalankan. Hal ini tentu bertentangan dengan prinsip-prinsip atau azasazas pelayanan prima. Tujuan pelayanan publik pada dasarnya adalah memuaskan masyarakat. Untuk mencapai kepuasan itu dituntut kualitas pelayanan publik yang profesional. Sinambela (2008 : 6) mengemukakan azas-azas pelayanan publik tercermin dari : 1) Transparansi, berifat terbuka, mudah diakses oleh semua pihak yang membutuhkan dan disediakan secara memadai serta mudah dimengerti. 2) Akuntabilitas, dapat dipertanggungjawabkan sesuai dengan ketentuan peraturan perundang-undangan. Masyarakat masih belum merasa puas atas pelayanan yang diterimanya. Pelayanan yang diberikan tidak sesuai dengan prosedur dan aturan yang berlaku.

Kesimpulan dari paparan tersebut di atas untuk dimensi Kualitas layanan masih rendah, masih belum diterapkan padahal menurut Dwiyanto Kualitas Layanan adalah dengan mengukur kepuasan masyarakat terhadap layanan yang di berikan. (Dwiyanto (2002) dalam Sudarmanto (2015:16))

3. Responsitas 
Keinginan para pegawai / staf membantu semua pelanggan serta berkeinginan dan melaksanakan pemberian pelayanan dengan tanggap. Dimensi ini menekankan pada sikap dari penyedia jasa yang penuh perhatian, cepat dan tepat dalam menghadapi permintaan, pertanyaan, keluhan dan masalah dari pengguna layanan. Dimensi Responsitas ini merefleksikan komitmen instansi untuk memberikan pelayanan yang tepat pada waktunya dan persiapan instansi sebelum memberikan pelayanan.

Berikut adalah kutipan wawancara ketika ditanya tentang bagaimana respon petugas terhadap keluhan yang warga/pengguna layanan hadapi. Menurut SR (Wanita,25 tahun wawancara tgl.17 Nopember 2019) : "ada petugas yang cukup baik menanggapi keluhan saya,tapi ada juga yang kayanya agak males kaya judes gitu a kalo tanyatanya teh..jawabnya aga ketus.." TE(Pria,42 tahun) : "Biasa aja petugas kalo ngasih penjelasan, kadang ada yang seperlunya kalo ditanya jawab, kalo ga ya ga dijelasin"...HN (Pria,49 tahun) : "Saya pernah sempat tanya-tanya koq biaya perijinan sampe segitu, tapi jawabannya ga jelas mas.."..WA (Pria,18 tahun) :"..iya nih,udah jam segini koq masih belum buka ya a..padahal saya harus buru-buru mau urus-urus buat ke rumah sakit.."..hal lain diungkapkan AT(wanita, 35 tahun) : " sekarang udah jam 8 lewat,tapi petugas nya pada belum datang jadi terpaksa saya nunggu aga lama a. datang dari jam setengah delapan."

Pelayanan prima adalah pelayanan yang sangat baik dan melampaui harapan pelanggan (Rahmayanti, 2010). Pelayanan prima bertujuan memberikan pelayanan yang dapat memenuhi dan memuaskan pelanggan atau masyarakat serta memberikan fokus pelayanan kepada pelanggan. Berdasarkan wawancara tersebut di atas petugas pelayanan masih belum menjalankan tugasnya dengan baik terbukti dari keluhan masyarakat saat wawancara. Berikut kutipan wawancara dengan Kepala Seksi Pelayanan Umum selaku narasumber : "Kami berusaha menanggapi berbagai keluhan,masukan,kritik yang diberikan masyarakat atas pelayanan yang kami berikan..kami berusaha semaksimal mungkin untuk meningkatkan pelayanan ini..mungkin sambil berjalan kita akan terus berupaya memperbaiki kekurangan yang ada..kami harap maklum karena beberapa orang dari petugas khususnya di pelayanan adalah tenaga sukarela dan honorer jadi mungkin mereka masih dalam tahap pembelajaran". Kepuasan adalah perasaan senang seseorang yang berasal dari perbandingan antara kesenangan terhadap aktifitas dan suatu produk dengan harapannya." Kepuasan adalah perasaan senang atau kecewa seseorang yang muncul setelah membandingkan antara persepsi atau kesannya tehadap kinerja atau hasil produk dan harapan-harapannya. Kotler (2004 dalam Nursalam,2011). Untuk terwujudnya pelayanan prima khususnya di seksi pelayanan umum ini seyogyanya dilakukan oleh petugas baik yang berstatus pegawai tetap maupun yang tidak. Meskipun ada petugas yang masih berstatus bukan pegawai tetap / honor hendaknya hal itu tidak membuat pelayanan menjadi tidak optimal. Pembekalan pengetahuan dan pemahaman akan tupoksi yang baik sebelum betugas akan membuat petugas melaksanakan tugasnya dengan baik pula sehingga pelayanan yang prima dapat diterima oleh masyarakat.

Berdasarkan pada hasil wawancara dengan narasumber tersebut di atas untuk dimensi Responsitas dapat diketahui bahwa kualitas pelayanan seksi pelayanan umum SKPD kecamatan subang masih rendah dan belum menerapkan dimensi ini padahal menurut Dwiyanto Responsivitas merupakan mengukur kemampuan 
organisasi untuk mengenali kebutuhan masyarakat,menyusun agenda dan prioritas pelayanan,dan mengembangkan program-program pelayanan publik sesuai dengan kebutuhan dan aspirasi masyarakat. (Dwiyanto (2002) dalam Sudarmanto (2015:16))

4. Responsibilitas

Responsibilitas merupakan menjelaskan atau mengukur kesesuaian pelaksanaan kegiatan organisasi publik yang dilakukan dengan prinsip - prinsip administrasi yang benar atau sesuai dengan kebijakan organisasi.

Warga masyarakat yang membutuhkan pelayanan di kantor Kecamatan Subang datang dengan berbagai karakteristik terutama dalam hal tingkat pendidikan, sehingga pada situasi tersebut dibutuhkan informasi tentang pelayanan yang akan maupun sudah diberikan guna mengurangi kesalahpahaman antara penyedia layanan dengan pelanggan (Brunner dan Suddarth, 2002). Berikut petikan wawancara mengenai dimensi ini : RI (Pria,51 tahun,16 Nopember 2019) : "Para pegawai yang di pelayanan ada beberapa yang kurang paham juga kayanya untuk ngejelasin syarat-syarat bikin ijin,saya mau bikin HO.. jadi saya harus bolak balik ke kelurahan ngelengkapin berkas yang kurang,,kurang sosialisasi gitu mas.." Berdasarkan wawancara di atas kinerja pelayanan publik pada seksi pelayanan umum ini belum memahami syarat- syarat perizian sehingga tingkat kepuasan masyarakat tidak pernah diukur. Kemungkinan lainnya adalah karena petugas pelayanan tidak atau kurang mematuhi standar pelayanan yang telah ditetapkan, sehingga kinerja pelayanan tidak seperti yang diharapkan. Berikut petikan wawancara dengan Camat Subang terkait dimensi ini : "Kami berusaha memberikan pelayanan yang baik..adapun kekurangan mungkin merupakan proses dari pembelajaran staf kami..dan saya sudah intruksikan untuk berhati-hati dan cermat dalam bertugas termasuk harus rapih dalam pengelolaan arsip administrasi baik yang di perijinan maupun yang non perijinan.." Petugas pelayanan hendaknya menjamin bahwa semua hal terkait pelayanan khusunya pegelolaan arsip administrasi dijalankan dengan baik dan benar sesuai prosedur yang berlaku agar masyarakat merasa puas dengan pelayanan yang diberikan.

Secara teoritis, tujuan pelayanan publik adalah memuaskan masyarakat. Azas-azas dalam pelayanan publik tercermin dari : 1) Partisipatif, mendorong peran serta masyarakat dalam penyelenggaraan pelayanan publik dengan memperhatikan aspirasi, kebutuhan dan harapan masyarakat 2) Keseimbangan Hak dan Kewajiban, pemberi dan penerima pelayanan publik harus memenuhi hak dan kewajiban masing-masing pihak. Berdasarkan paparan tersebut di atas, dari dimensi Responsibilitas dapat disimpulkan bahwa petugas pelayanan pada seksi pelayanan umum belum bekerja secara optimal, hal ini terlihat dari masih adanya kekurangan dalam hal pengelolaan kearsipan, berkas-berkas pelayanan yang disimpan sebagai arsip bilamana dibutuhkan. Padahal menurut Dwiyanto Responsilibitas merupakan menjelaskan \mengukur kesesuaian pelaksanaan kegiatan organisasi publik yang di lakukan dengan prinsip-prinsip administrasi yang benar atau sesuai dengan kebijakan organisasi. (Dwiyanto (2002) dalam Sudarmanto (2015:16))

5. Akuntabilitas

Dalam hal ini karyawan / petugas pelayanan harus mampu menempatkan dirinya pada pelanggan / pengguna layanan, dapat berupa kemudahan dalam menjalin hubungan dan komunikasi termasuk perhatiannya terhadap para pelanggannya, 
serta dapat memahami kebutuhan pelanggan. Berikut petikan wawancaranya : LM (Wanita,36 tahun,21 Nopember 2019):" Menurut saya petugas pelayanan cukup baik ya mas...."Hal lain diungkapkan IR (wanita,42 tahun) : "Menurut saya saat memberikan pelayanan petugas disini cukup ramah,kadang ada sambil becanda nya a..jadi tidak terkesan formal a...". Berdasarkan wawancara dengan masyarakat di atas, dilihat dari dimensi akuntabilitas ini petugas pelayanan cukup baik dalam melaksanakan tugas nya. Berikut petikan wawancara dengan Kasi Pelayanan Umum :" Ya kami berusaha sebaik mungkin melayani warga yang datang..saya minta kepada staf untuk berusaha ramah kepada warga agar mereka merasa puas.."Salah seorang staf (HL,wanita,34 tahun) mengatakan :" Iya kami berusaha untuk memberikan kesan yang baik terhadap warga yang datang,intruksi dari pimpinan juga seperti itu.." Pada dimensi ini berkaitan erat dengan interpretasi secara personal bagi pegawai yang memiliki keinginan yang baik dalam memberikan pelayanan kepada pelanggannya, hal ini tentu akan memberikan manfaat positif bagi pegawai itu sendiri dan bagi kantor kecamatan subang pada umumnya dalam membangun hubungan yang lebih baik dengan pengguna layanan.

Akuntabilitas dalam suatu organisasi kerja menjadi sangat penting dalam memberikan suatu kualitas layanan sesuai prestasi kerja yang ditunjukkan oleh pegawai menurut Dwiyanto Akuntabilitas merupakan seberapa besar kebijakan dan kegiatan organisasi publik tunduk pada para pejabat politik yang dipilih oleh rakyat atau ukuran yang yang menunjukan tingkat kesesuaian penyelenggaraan pelayanan dengan ukuran nilai-nilai atau norma eksternal yang ada di masyarakat atau yang di miliki para stakeholders. Berdasarkan petikan wawancara di atas untuk dimensi ini dapat disimpulkan bahwa petugas pelayanan cukup baik dalam melaksanakan tugasnya. (Dwiyanto (200) dalam Sudarmanto (2015:16))

\section{Kesimpulan}

Dari hasil penelitian yang dilakukan serta pembahasan maupun analisis data, diperoleh beberapa kesimpulan tentang kualitas pelayanan pada seksi pelayanan umum SKPD Kecamatan Subang sebagai berikut : 
1. Produktivitas

Perlu adanya evaluasi dan perbaikan sarana penunjang pelayanan seperti perbaikan mesin antrian, penambahan tempat duduk di ruang tunggu dan pengecekan pengatur suhu ruangan secara berkala. Hal ini tentunya dapat terlaksana apabila ada dukungan dan komitmen dari semua pegawai baik unsur pimpinan maupun staf pada SKPD Kecamatan Subang sehingga nantinya pelayanan akan berjalan optimal dan dapat sepenuhnya memuaskan pengguna layanan. Kualitas Pelayanan Pada Seksi Pelayanan Umum SKPD Kecamatan Subang untuk dimensi ini masih rendah.

2. Kualitas Layanan

Pada dimensi ini masih ditemukannya ketidakpuasan pelanggan maka pada dimensi ini dikategorikan tidak optimal dan masih harus ditingkatkan. Azaz transparansi atau keterbukaan harus benar-benar diterapkan dalam hal pemberian pelayanan khususnya pelayanan di bidang perijinan dan non perijinan. Pemberian pelayanan haruslah benar-benar sesuai dengan aturan yang ada. Kualitas Pelayanan Pada Seksi Pelayanan Umum SKPD Kecamatan Subang untuk dimensi ini masih rendah.

3. Responsitas

Dengan masih adanya ketidakpuasan pada masyarakat pengguna layanan maka pada dimensi ini dikategorikan kurang optimal dan masih harus terus ditingkatkan. Pegawai harus menyadari tugas pokok dan fungsi nya sebagai pemberi / penyedia layanan kepada masyarakat dalam hal ini yang mengakses pada seksi pelayanan umum dengan memberikan respon cepat dan tanggap atas keluhan, saran dan kritik. Kualitas Pelayanan Pada Seksi Pelayanan Umum SKPD Kecamatan Subang untuk dimensi ini masih rendah.

4. Responsibilitas

Pada dimensi ini juga masih kurang optimal, perlu adanya komitmen dari staf pelaksana dan pejabat terkait pelayanan untuk terus meningkatkan kualitas pelayanan dengan berpegang teguh pada aturan yang ada agar masyarakat merasa aman dan percaya. Dapat memberikan jaminan kepercayaan salah satunya dengan pengelolaan arsip pelayanan yang baik. Kualitas Pelayanan Pada Seksi Pelayanan Umum SKPD Kecamatan Subang untuk dimensi ini masih rendah.

5. Akuntabilitas

Pada dimensi ini kualitas pelayanan yang ada sudah cukup baik terbukti dengan hasil wawancara dengan para narasumber yang menyatakan pandangan positif atas sikap pegawai yang memberikan pelayanan. Pada Seksi Pelayanan Umum SKPD Kecamatan Subang dimensi ini sudah dilaksanakan dengan cukup baik.

\section{Referensi}

Cushway, Barry. 2002. Human Resources Management. Jakarta : PT.Gramedia.

Dwiyanto, Agus. 2008. Reformasi Birokrasi Publik Di Indonesia. Pusat Studi Kependudukan dan Kebijakan, Universitas Gadjah Mada,Yogyakarta. 


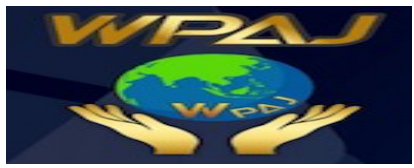

Volume 2 Issue 2, Desember 2020 http://ejournal.unsub.ac.id/index.php/publik

Handoko. T. Hani. 2009. Manajemen,.Yogyakarta : BPFE.

Hasibuan, Malayu SP. 2001. Manajemen Sumber Daya Manusia. Jakarta : PTBumi Aksara.

Inu. Kecana S. 2006. Ilmu Administrasi Publik. Jakarta : Rineka Cipta.

Mahmudi. 2005. Perilaku Organisasi. Jakarta : Selemba Empat.

Mangkunegara. 2000. Manajemen Sumber Daya Manusia. Bandung : PT Remaja Rosdakarya

Marbun, SF \& Mahfud MD. Moh. 2006. Pokok-pokok Hukum Administrasi Negara. Liberty Yogyakarta.

Mashun. 2006. Pengukuran Kinerja Sektor Publik. Cetakan Pertama, Yogyakarta : BPFE.

Moleong, lexy J. 2005. Metode Penelitian Kualitatif. Bandung : PT. Remaja Rosdakarya.

Pasolong, Harbani. 2010. Teori Administrasi Publik. Bandung. Alfabetha.

Pemerintahan Daerah Kabupaten Subang No. 12 Tahun 2000 Tentang Ijin Mendirikan Bangunan.

Ruky.2001. Sistem Manajemen Kinerja. Jakarta : PT. Gramedia. Pustaka Utama.

Sudarmanto. 2015. Kinerja dan Pengembangan Kompetensi SDM. Yogyakarta : Pustaka Pelajar.

Sugiyono. 1998. Metode Penelitian Administrasi. Bandung: Alfabeta.

Sulistiyani. 2003. Manajemen Sumber Daya Manusia. Yogyakarta : Graha Ilmu.

Tangkilisan. 2005. Manajemen Publik. Jakarta : Gramedia Widia.

Undang-undang No. 34 Tahun 2004, Tentang Otonomi Daerah.

Undang-undang No. 25 Tahun 2009, Tentang Pelayanan Publik.Peraturan

Wibowo. 2016. Manajemen Kinerja. Bandung : PT. Raja Grapindo. 